\title{
TEORI FRAUD PENTAGON dan DETEKSI KECURANGAN PELAPORAN KEUANGAN
}

\author{
Nova Novita* \\ STIE Indonesia Banking School, Jalan Kemang Raya no 35, Jakarta Selatan \\ Nova.novita@ibs.ac.id
}

\author{
A R T I C L E I N F O \\ Article history: \\ Received February 12, 2019 \\ Revised March 26, 2019 \\ Accepted April 5, 2019
}

Key words:

Fraud Triangle Theory, Fraud Diamond Theory, Fraud Pentagon Theory

\begin{abstract}
A B S T R A C T
The purpose of this research is to investigate whether the fraud pentagon theory predictors, namely: Pressure, Opportunity, Rationalization, Capability and Arrogance able to explain the probability of financial statement of fraud occurrence in Indonesia. The results show that: only Pressure and Rationalization elements can define the likelihood of financial statement fraud. The Capability and Arrogance proxies proposed in this research are not proven to explain the opportunities for financial statement fraud. This research finding shows that the fraud pentagon theory still needs testing in different contexts

A B S T R A K

Tujuan dari penelitian ini adalah untuk mengetahui apakah prediktor teori pentagon penipuan, yaitu: Tekanan, Peluang, Rasionalisasi, Kemampuan dan Keangkuhan mampu menjelaskan probabilitas laporan keuangan terjadinya kecurangan di Indonesia. Hasilnya menunjukkan bahwa: hanya elemen Tekanan dan Rasionalisasi yang dapat menentukan kemungkinan penipuan laporan keuangan. Proksi Kemampuan dan Keangkuhan yang diusulkan dalam penelitian ini tidak terbukti menjelaskan peluang untuk penipuan laporan keuangan. Temuan penelitian ini menunjukkan bahwa teori pentagon penipuan masih membutuhkan pengujian dalam konteks yang berbeda.
\end{abstract}

\section{PENDAHULUAN}

Data global fraud study yang dirilis oleh ACFE (2016) menunjukkan bahwa jumlah temuan kasus fraud terbanyak dalam kurun waktu 2012-2016 adalah dalam hal Asset misappropriation (86,7\% pada tahun 2016, $85,4 \%$ tahun 2014 dan $83,5 \%$ pada tahun 2012 ), diikuti oleh korupsi (33,4\% pada tahun 2016, 36,8\% tahun 2014 dan $35,4 \%$ pada tahun 2012) dan financial statement fraud $(7,6 \%$ pada tahun $2016,9 \%$ tahun 2014 dan $9,6 \%$ pada tahun 2012). Meski frekuensi temuan kasus terbanyak adalah pada Asset misappropriation, namun kerugian yang ditimbulkan oleh financial statement fraud adalah yang tertinggi.

Data global fraud study juga menunjukkan bahwa industri perbankan dan jasa keuangan, pemerintah dan industri manufaktur merupakan pelaku tindak kecurangan yang paling banyak. Lebih spesifik lagi, departemen yang paling banyak melakukan kecurangan adalah departemen akuntansi (16,6\%) jika dibandingkan dengan departemen lain. Sedangkan individu yang paling banyak ditemukan melakukan kecurangan adalah individu yang bekerja pada bagian akuntansi, operasional, penjualan, manajemen puncak, pelayanan pelanggan, pembelian dan keuangan. Hal yang paling mengejutkan dari laporan ACFE 2016 tersebut, sebanyak 40.7\% temuan kasus kecurangan, organisasi yang menjadi korban memutuskan tidak membawa kasus tersebut ke ranah hukum dengan alasan terbanyak menghindari publisitas buruk. Data tersebut selayaknya menjadi cermin bagi bidang ilmu dan profesi akuntansi untuk terus memperbaiki diri, baik dari sisi integritas individu, pendidikan akuntansi dan standar akuntansi.

Sebahagian besar riset mengenai kecurangan menyepakati bahwa pencegahan fraud seharusnya menjadi fokus utama penelitian (Abdullahi dan Mansor, 2015). karena biaya pencegahan fraud lebih murah dan efektif dibandingkan biaya kerugian fraud itu sendiri. Biasanya tindakan fraud akan ditemukan seiring dengan berjalannya waktu, namun demikian kerugian akibat kecurangan tersebut bersifat unrecoverable atau hanya dapat dikembalikan dalam jumlah yang tidak utuh (Abdullahi dan Mansor, 2015).

Sejumlah teori berusaha menjelaskan mengapa tindak kecurangan terjadi, tiga teori yang mengemuka adalah Fraud Triangle Theory (FTT) oleh Cressey (1953), Fraud Diamond Theory (FDT) oleh Wolfe dan Hermanson (2004) dan Fraud Pentagon Theory oleh Horwarth (2012). Ketiga teori tersebut mencoba untuk mengidentifikasi elemenelemen pendorong terjadinya fraud. Fraud Triangle Theory (FTT) mengindentifikasi tindakan fraud melalui tiga elemen yaitu: (i) perceived pressure, (ii) opportunity, and (iii) rationalization. Wolfe dan Hermanson (2004) kemudian menambahkan elemen keempat yaitu "capability", berdasarkan pertimbangan bahwa fraud tidak mungkin dil- 
akukan dengan sukses tanpa adanya kemampuan individu. Horwarth (2012) menambahkan elemen kelima fraud yaitu "Arrogance".

Pengujian terhadap teori fraud telah dilakukan di Indonesia seperti Annisya, Lindrianasari dan Asmaranti (2016) menemukan bahwa Financial Stability, External Pressure dan Opini Audit berpengaruh terhadap financal statement fraud, sedangkan pengukuran lainnya tidak memiliki pengaruh terhadap Financal Statement fraud. Tessa dan Harto (2016) menemukan bahwa financial stability, external pressure, dan frekuensi munculnya CEO's picture berpengaruh terhadap fraud ulent financial reporting. Sihombing (2014) menemukan bahwa variabel financial stability, external pressure, nature of industry dan rationalization terbukti berpengaruh terhadap financial statement fraud namun tidak membuktikan bahwa financial target, innefective monitoring, change in auditor, dan capability memiliki pengaruh terhadap financial statement fraud. Kurniawati (2012) menemukan bahwa pressure dan opportunity berpengaruh signifikan terhadap financial statement fraud, sedangkan rasionalisasi tidak berpengaruh. Molida (2011) menemukan ineffective monitoring tidak berpengaruh secara signifikan terhadap financial statement fraud. Norbarani (2012) menemukan bahwa external pressure memiliki hubungan negatif dengan financial statement fraud. Financial targets berhubungan positif terhadap financial statement fraud. Financial stability, personal financial need dan innefective monitoring tidak memiliki pengaruh terhadap financial statement fraud.

Penelitian fraud di Indonesia secara umum masih berfokus pada pengujian keandalan teori fraud dalam mendeteksi fraud dan menggunakan sampel dari jenis industri tertentu saja. Sebahagian besar riset terkait fraud menguji secara keseluruhan teori tersebut dalam satu model (ftt, fdt dan fpt). Riset ini menjadi penting karena berkontribusi dalam upaya pencegahan fraud pada perusahaan publik di indonesia. Penelitian ini selain menguji keandalan ketiga teori fraud juga akan menambahkan beberapa alternatif proksi pengukuran "capability" yaitu usia, pengalaman dan tingkat pendidikan, menggunakan risiko organisasi dan manajerial untuk mengukur "arrogance". Riset ini menguji kembali keseluruhan proksi yang telah di uji pada penelitian Skousen, Smith, dan Wright (2009) dengan menggunakan setting indonesia, hal ini didasari oleh adanya perbedaan situasi pasar modal di Indonesia dengan Amerika. Berdasarkan uraian di atas dapat disimpulkan bahwa tujuan riset ini adalah: (1) menguji apakah berbagai prediktor fraud triangle, fraud diamond dan fraud pentagon dalam menjelaskan financial statement fraud yang lebih sesuai dengan kondisi Indonesia. (2) menguji usulan alternatif proksi fraud diamond dan fraud pentagon.

\section{KAJIAN LITERATUR DAN PENGEMBANGAN HIPOTESIS}

The Fraud Triangle Theory

The fraud Triangle Theory, diajukan oleh Donald Cressey seorang kriminolog pada tahun 1950. Risetnya mengenai mengapa seseorang melakukan fraud melibat- kan 250 orang pelaku tindak criminal. Hasil interview mendalam kepada mereka menghasilkan tiga elemen fraud yaitu Pressure, Opportunity dan Rationalization. Pressure menunjukkan faktor-faktor yang mendorong seseorang kedalam perilaku tidak etis. Setiap pelaku tindak kecurangan mengalami kondisi tekanan sebelum mereka melakukan tindakan fraud (Abdullahi dan Mansor, 2015). Tekanan tersebut dapat berupa tekanan keuangan atau non keuangan. Tekanan finansial merupakan faktor yang paling umum menyebabkan adanya fraud (Albrecht, Albrecht dan Albrecht, 2008). Skousen dkk. (2009) membagi empat elemen lagi sebagai proksi dari pressure, yaitu financial stability, external pressure, managers' personal financial situations, dan meeting financial targets. Semakin tinggi pressure yang dirasakan oleh seorang individu, akan semakin besar peluangnya

Opportunity terjadi akibat adanya ketidakefektifan pada sistem pengendalian internal atau tata kelola, sehingga memungkinkan individu untuk melakukan fraud. SAS No. 99 (2002) mengklasifikasikan opportunities kedalam tiga kategori yaitu nature of industry, ineffective monitoring dan organizational structure. semakin tinggi opportunity yang diberikan, semakin mendorong seseorang untuk melakukan fraud.

Rationalization, mengindikasikan bahwa pelaku harus memiliki penerimaan secara moral terhadap fraud sebelum dia melakukan tindakan yang tidak etis. Rasionalisasi menunjukkan justifikasi dan penerimaan bahwa tindak non etis berbeda dengan aktivitas criminal. Rasionalisasi merupakan elemet ketiga fraud yang paling sulit untuk di ukur. Skousen dkk. (2009) mengukur rasionalisasi melalui pergantian auditor, total akrual dan opini audit.

\section{The Fraud Diamond Theory}

The Fraud Diamond Theory, dirumuskan oleh Wolfe dan Hermanson (2004). Teori ini di pandang sebagai pengembangan dari Fraud Triangle Theory. Teori ini menambahkan capability sebagai salah satu elemen yang mempengaruhi mengapa seseorang melakukan kecurangan. Capability adalah situasi yang memerlukan keahlian dan kemampuan dari seseorang untuk melakukan tindak kecurangan. Fraud yang melibatkan angka milyaran bahkan triliunan tidak akan terjadi tanpa adanya orang yang tepat dengan keahlian yang tepat. Berdasarkan pengalaman Wolfe dan Hermanson (2004) dalam menginvestigasi fraud selama lebih dari 15 tahun, terdapat beberapa kondisi yang mendukung adanya fraud, terutama terkait elemen capability. Pertama, posisi seseorang atau fungsinya dalam organisasi memberikannya kemampuan untuk membuat atau memanfaatkan kesempatan untuk berbuat curang yang tidak dimiliki oleh orang lain. Kedua, orang yang tepat untuk melakukan fraud adalah memiliki kepintaran yang cukup untuk memahami dan mengeksploitasi kelemahan pengendalian internal dan menggunakan posisi, fungsi, atau fungsi otorisasi untuk menghasilkan keuntungan yang besar. Hal ini didukung oleh data ACFE (2016) bahwa 51\% dari pelaku kecurangan memiliki setidaknya gelar sarjana, $49 \%$ dari pelaku berusia 
lebih dari 40 tahun dan $46 \%$ dilakukan oleh manajer atau pimpinan perusahaan. Ketiga, pelaku fraud memiliki ego yang kuat dan keyakinan besar bahwa ia tidak akan terdeteksi, atau orang lain percaya bahwa ia bisa dengan mudah keluar dari kesulitan jika tertangkap. Keempat, penipu sukses bisa memaksa orang lain untuk melakukan atau menyembunyikan penipuan. Seseorang dengan kepribadian yang sangat persuasif mungkin dapat meyakinkan orang lain untuk melakukan kecurangan. Kelima, penipu ulung berbohong secara efektif dan konsisten. Dia juga memiliki keterampilan untuk menjaga kebohongan, sehingga cerita kecurangan secara keseluruhan tetap konsisten. Terakhir, sebuah penipu sukses sangat mampu mengelola stres dengan baik. Melakukan penipuan dan mengelola penipuan selama periode waktu yang panjang bisa mengakibatkan stress berkepanjangan.

Capability dalam kerangka Fraud Diamond Theory ini diukur berdasarkan usia, pengalaman, dan tingkat pendidikan CEO mengacu pada capability factor yang disebutkan oleh ACFE (2016) serta pergantian direksi serta pergantian direksi sebagaimana digunakan dalam penelitian (Tessa dan Harto, 2016). Semakin matang usia seorang CEO, semakin baik pengendalian dirinya, sehingga akan lebih tenang dalam merencanakan fraud. Semakin berpengalaman seorang CEO, akan semakin mampu dalam menyusun rencana fraud dengan baik. Semakin tinggi tingkat pendidikan seorang CEO, akan semakin tinggi pemahaman keilmuannya dan semakin baik dalam mengantisipasi risiko yang ditimbulkan dari tindakan fraud.

\section{The Fraud Pentagon Theory}

Fraud Pentagon yang akan di bahas dalam riset ini menggunakan dua elemen dari dua peneliti yang berbeda yaitu elemen kelima yang diajukan oleh Horwarth, 2012). Elemen fraud kelima yang diajukan oleh Horwarth (2012) adalah Arrogance. Kesombongan atau kurangnya kesadaran merupakan sikap superioritas dan hak atau keserakahan dari seseorang yang meyakini bahwa pengendalian internal merupakan hal yang sepele dan tidak perlu diterapkan secara personal. Sebahagian besar pelaku fraud dilakukan oleh orang yang berada pada posisi sangat senior dengan Big Egos, yang meyakini bahwa aturan tidak berlaku bagi diri mereka, mereka berfikir bahwa dapat menghindari kontrol internal dan tidak akan terdeteksi dalam melakukan kecurangan. Banyak tindakan kriminal dilakukan tanpa adanya keuntungan ekonomi karena alasan ego, status, dan kesombongan belaka.

Kasus Enron menunjukkan bahwa kecurangan yang dilakukan berhubungan dengan karakter manajemen puncak yang cenderung, individualis, agresif, serakah, kejam, ambisi untuk menang dengan cara apapun, keberanian yang berlebihan dalam mengambil risiko, berorientasi jangka pendek serta mentolerir sikap menghindari aturan yang berlaku (Jeppesen dan Leder, 2016). Arogansi pimpinan perusahaan akan terlihat dari kebijakan yang diambil perusahaan, dan tercermin dari tingkat risiko perusahaan. Pimpinan yang arogan tidak akan ragu menempatkan perusahaan yang dipimpinnya berada dalam risiko tinggi. Dengan demikian dapat disimpulkan bahwa semakin tinggi arogansi pimpinan, akan semakin berani pimpinan dalam mengambil risiko dan pada akhirnya akan berdampak pada tingkat risiko perusahaan. Dengan kata lain, semakin tinggi tingkat arogansi, maka akan semakin tinggi pula risiko perusahaan. Riset mengenai risiko membagi risiko menjadi dua, yaitu organizational risk yang didefinisikan sebagai "income stream uncertainty" dan managerial risk yang terjemahkan sebagai "management's proactive choices regarding allocation of resources" (Palmer dan Wiseman, 1999). Khanin dan Mahto (2012) telah membuktikan bahwa baik risiko manajerial maupun risiko organisasi cenderung mempengaruhi tindakan kecurangan perusahaan. Riset ini akan menggunakan dua proksi risiko yaitu risiko organisasi dan risiko manajerial sebagai proksi dari arogansi.

\section{Financial Statement Fraud}

ACFE (2014) menyatakan bahwa kecurangan pada laporan keuangan adalah penipuan disengaja yang dilakukan oleh seorang manajer atau karyawan dengan tidak memberikan informasi keuangan yang sebenarnya, misalnya, pendapatan fiktif, melaporkan biaya terlalu rendah dan sebagainya. Perusahaan publik dan sektor swasta memiliki kesempatan untuk manipulasi laba (Tarjo dan Herawati, 2015). Kecurangan pada laporan keuangan, dibagi kedalam lima klasifikasi umum: menyamarkan pendapatan, perbedaan waktu, menyembunyikan liabilitas dan beban, pengungkapan yang tidak salah, pengakuan aset yang tidak tepat (Repousis, 2016).

Tantangan terbesar bagi peneliti pelaporan keuangan adalah bahwa mereka tidak selalu mampu dalam mengobservasi dan mengukur manajemen laba. Kaminski dan Guan (2004) menemukan bahwa rasio keuangan memiliki keterbatasan dalam mendeteksi kecurangan dalam laporan keuangan. Beneish M-Score adalah metode yang dapat digunakan untuk mendeteksi apakah sebuah perusahaan memiliki kecenderungan untuk melakukan fraud pada laporan keuangannya (Beneish, 2012). Beneish M-Score <2.2 menunjukkan bahwa perusahaan tidak tergolong ke dalam manipulator, sedangkan skore $>2.2$ menunjukkan sinyal bahwa perusahaan besar kemungkinannya melakukan manipulasi (Repousis, 2016). Meski demikian, Beneish M-Score adalah model yang bersifat probabilitistik, sehingga keakuratan 100\% tidak dapat dicapai.

\section{Fraud Pentagon Element dan Financial Statement fraud}

Marianan dan Hakim (2016) meneliti kemampuan fraud triangle theory dalam menjelaskan manipulasi laba dalam laporan keuangan dan dampaknya terhadap adopsi IFRS. Hasil penelitian menunjukkan bahwa Pressure berpengaruh positif terhadap peluang manipulasi laba. Variabel opportunity memiliki pengaruh negatif terhadap peluang manipulasi laba. Sementara Rationalization tidak berpengaruh terhadap peluang manipulasi laba. IFRS sebagai variabel moderasi pada penelitian ini 
menurunkan dampak pressure terhadap peluang manipulasi laba. Sedangkan untuk opportunity dan rationalization, ketika dimoderasi dengan IFRS tidak dapat menurunkan peluang manipulasi laba. Yesiariani dan Rahayu (2016) meneliti empat faktor fraud diamond yang mendorong terjadinya fraud yaitu pressure, opportunity, rationalization dan capability. Sampel yang digunakan dalam penelitian ini adalah 22 perusahaan yang tergolong kedalam indeks LQ-45 dari tahun 2010-2014. Hasil penelitian menunjukkan bahwa external pressure dan rationalization terbukti berpengaruh positif terhadap kecurangan pelaporan keuangan. Sedangkan variabel financial stability, financial targets, change of auditor, personal financial need, nature of industry, ineffective monitoring dan capability tidak terbukti mempengaruhi kecurangan pelaporan keuangan.

Tessa dan Harto (2016), menguji dampak elemen yang terdapat dalam fraud pentagon theory terhadap fraudulent financial reporting perusahaan sektor keuangan dan perbankan periode 2012-2014. Hasil penelitian menyimpulkan bahwa financial stability, external pressure, dan the frequent number of CEO's picture berpengaruh dalam pendeteksian fraud ulent of financial reporting. Annisya dkk. (2016) melakukan pendeteksian kecurangan laporan keuangan dengan menggunakan fraud Diamond Theory. Hasil penelitian menunjukkan bahwa Financial Stability, External Pressure dan Opini Audit berpengaruh terhadap Financal Statement fraud. Sedangkan pengukuran lainnya tidak memiliki pengaruh terhadap Financal Statement fraud. Manurung dan Hardika (2015) menguji kemampuan fraud diamond theory dalam mendeteksi kecurangan dalam laporan keuangan. Riset ini menggunakan perusahaan perbankan publik dari periode 2012-2014. Hasil penelitian menunjukkan bahwa financial stability, external pressure dan financial targets; Nature of the Industry, Ineffective Monitoring dan change in the Auditor tidak mempengaruhi financial statement fraud sedangkan pergantian direksi berpengaruh positif terhadap Financial Statement fraud. Ardiyani dan Utaminingsih (2015) menganalisis determinan Financial Statement fraud melalui Pendekatan fraud Triangle. Dengan menggunakan External Pressure (LEV), Nature of Industry (INVENTORY), Rationalization (TACC, AUDREPORT) diperoleh hasil tidak ada satupun pengukuran yang memiliki pengaruh signifikan terhadap Financal Statement fraud. Khanin dan Mahto (2012) meneliti mengenai dampak regulatory risk, borderline legality terhadap fraud dan financial restatement. Riset ini menggunakan 868 perusahaan yang tercatat melakukan restatement oleh SEC selama Januari 1997 hingga Juni 2002. Hasil penelitian menunjukkan bahwa sikap perusahaan terkait regulatory risk berhubungan dengan organizational slack, risk dan auditor's rating. Riset ini juga menemukan bahwa kecenderungan perusahaan terlibat dalam fraud, dipengaruhi oleh type of slack accumulated and available in the firm. Perusahaan yang tergolong kedalam risk-averse cenderung memiliki risiko manajerial dan kebangkrutan yang kecil serta cenderung memperoleh penilaian yang tinggi dari auditor.
Berdasarkan Fraud Pentagon Theory di atas maka hipotesis utama yang diajukan pada penelitian ini adalah:

H1: Semakin besar pressure maka semakin besar pula peluang perusahaan melakukan financial statement fraud.

H2: Semakin besar opportunity maka semakin besar pula peluang perusahaan melakukan financial statement fraud.

H3: Semakin kuat rationalization maka semakin besar pula peluang perusahaan melakukan financial statement fraud.

H4: Semakin tinggi capability pimpinan maka semakin besar pula peluang perusahaan melakukan financial statement fraud.

H5: Semakin besar arogansi pimpinan perusahaan maka semakin besar pula peluang perusahaan melakukan financial statement fraud.

\section{METODE PENELITIAN}

\section{Data dan Sampel}

Penelitian ini menggunakan data sekunder, dengan seluruh perusahaan publik non keuangan dan perbankan di Indonesia 2013-2016. Hal ini dilakukan agar hasil penelitian ini dapat merangkum fenomena mengenai financial statement fraud yang terjadi di Indonesia.

\section{Operasionalisasi Variabel}

Variabel independen dalam penelitian ini adalah Financial statement fraud diukur dengan menggunakan Beneish M Score yang diformulasikan oleh Beneish (2012), yaitu:

$$
\begin{aligned}
\mathrm{M}= & -4.840+0,920 \text { XDSRI + 0,528XGMI + 0,0404XAQI + } \\
& \text { 0,892XSGI + 0,115XDEPI-0,172XSGAI + } \\
& \text { 4,679X/TATA- 0,327XLVGI }
\end{aligned}
$$

\begin{tabular}{|c|c|c|}
\hline 1 & $\begin{array}{c}\text { Days } \\
\text { Sales in } \\
\text { Receiv- } \\
\text { able } \\
\text { Index } \\
\text { (DSRI) }\end{array}$ & $D S R I=\frac{(\text { Net Receivables } \mathrm{t} / \text { Sales } \mathrm{t})}{(\text { Net Receivables } \mathrm{t}-1 / \text { Sales } \mathrm{t}-1)}$ \\
\hline 2 & $\begin{array}{l}\text { Gross } \\
\text { Margin } \\
\text { Index } \\
(\mathrm{GMI})\end{array}$ & $G M I=\frac{[(\text { Salest }-1-\text { COGSt }-1) / \text { Salest }-1]}{[(\text { Sales } \mathrm{t}-\text { COGSt }) / \text { Sales } t]}$ \\
\hline 3 & $\begin{array}{l}\text { Asset } \\
\text { Quality } \\
\text { Index } \\
\text { (AQI) }\end{array}$ & $A Q I=\frac{[\mathrm{TAt}-(\mathrm{CAt}+\mathrm{PPEt}) / \mathrm{TAt}]}{[\mathrm{TAt}-1-(\mathrm{CAt}-1+\mathrm{PPE} \mathrm{t}-1) / \mathrm{TAt}-1]}$ \\
\hline 4 & $\begin{array}{l}\text { Sales } \\
\text { Growth } \\
\text { Index } \\
\text { (SGI) }\end{array}$ & $S G I=\frac{\text { Sales } \mathrm{t}}{\text { Sales } \mathrm{t}-1}$ \\
\hline 5 & $\begin{array}{l}\text { Depre- } \\
\text { ciation } \\
\text { Index } \\
\text { (DEPI) }\end{array}$ & $D E P I=\frac{[(\text { Depreciation } \mathrm{t}-1 /(\operatorname{PPE} \mathrm{t}-1+\text { Depreciation } \mathrm{t}-1)]}{[(\text { Depreciation } \mathrm{t} /(\mathrm{PPE} \mathrm{t}+\text { Depreciation } \mathrm{t})]}$ \\
\hline 6 & $\begin{array}{c}\text { Sales } \\
\text { General } \\
\text { and } \\
\text { Admin- } \\
\text { istra- } \\
\text { tive } \\
\text { Ex- } \\
\text { pense }\end{array}$ & $\mathrm{SGAI}=\frac{(\text { Sales General and Expenses } \mathrm{t} / \text { Sales } \mathrm{t})}{(\text { Sales General and Expenses } t-1 / \text { Sales } t-1)}$ \\
\hline
\end{tabular}

Dimana:

Tabel 1. Operasionalisasi Variabel 


\begin{tabular}{|c|c|c|}
\hline & $\begin{array}{l}\text { Index } \\
\text { (SGAI) }\end{array}$ & \\
\hline 7 & $\begin{array}{l}\text { Lever- } \\
\text { age } \\
\text { Index } \\
\text { (LVGI) }\end{array}$ & LVGI $=\frac{[(\text { Current Liabilietes } \mathrm{t}+\text { Long Term Debt } \mathrm{t}) / \text { Total Assets }]}{[(\text { Current Liabilities } \mathrm{t}-1+\text { Long Term Debt } \mathrm{t}-1) / \text { Total Assets } \mathrm{t}-1]}$ \\
\hline 8 & $\begin{array}{c}\text { Total } \\
\text { Accru- } \\
\text { als to } \\
\text { Total } \\
\text { Assets } \\
\text { (TATA) }\end{array}$ & $\mathrm{TATA}=\frac{(\mathrm{NI} \text { from Continuing Operations } \mathrm{t}-\text { Cash Flows from Operations } \mathrm{t})}{\text { Total Assets } \mathrm{t}}$ \\
\hline
\end{tabular}

Sumber: Beneish (2012)

Variabel Independen (Fraud Triangle, Diamond and Pentagon)

a. Pressure, diukur melalui Financial stability, External pressure, Personal financial need dan Financial targets.

Financial stability, ketika posisi laba perusahaan berada di bawah rata-rata industri, manajemen akan memanipulasi laporan keuangan perusahaan agar terlihat berkinerja baik. Sebaliknya jika posisi perusahaan berada di atas rata-rata industri, manajemen tetap akan memanipulasi laporan keuangan agar, laba perusahaan terlihat stabil. Penelitian ini menggunakan proksi persentase perubahan aset dalam 2 periode mengikuti Beneish (1997) dan Beasley, Carcello, Hermason dan Lapides (2000) yang telah terbukti signifikan dalam Skousen dkk. (2009).

External pressure, sumbernya biasanya berasal dari tuntutan terpenuhinya exchange-listing, melunasi utang atau memenuhi kontrak utang. Riset ini menggunakan proksi Finance, yang dirumuskan oleh Dechow, Ge dan Schrand (2009). Ketika nilai Finance negatif, nilai absolut dari rasio 1 /Finance mengindikasikan jumlah tahun dimana perusahaan mampu menggunakan sumber dana internal dalam membiayai aktivitas perusahaan. Semakin negatif nilai Finance, semakin tinggi tekanan untuk melakukan manipulasi pada laporan keuangan. Semakin nilai absolut Finance mendekati nol, semakin besar kebutuhan perusahaan pada sumber pembiayaan eksternal. Kebutuhan akan pembiayaan eksternal, berhubungan dengan kas yang dihasilkan dari kegiatan operasional dan investasi perusahaan. Riset ini juga menggunakan Freec, yang terbukti signifikan sebagai proksi dari eksternal pressure (Skousen dkk., 2009).

Personal financial need, ketika eksekutif perusahaan memiliki kepentingan keuangan yang signifikan, maka kondisi keuangannya akan dipengaruhi oleh kondisi keuangan perusahaan. Sehingga digunakan proksi Oship dan 5\%Own sebagai proksi Personal financial need dan telah terbukti signifikan dalam penelitian Skousen dkk. (2009).

Financial targets, Return on Assets (ROA) merupakan ukuran kinerja yang dipakai secara luas, yang menunjukkan seberapa efisien pengelolaan aset perusahaan. ROA sering digunakan sebagai alat penilaian kinerja manajer dan dasar pemberian bonus, kenaikan gaji dan sebagainya. Riset ini kemudian menggunakan ROA sebagai proksi dari Financial target.

b. Opportunity, SAS no.99 mengklasifikasikan opportunity kedalam tiga kategori yaitu: Nature of industry, ineffective monitoring and organizational structure.

Nature of industry, saldo pada akun tertentu dihitung umumnya dengan menggunakan estimasi dan judgment yang bersifat subjektif. Dalam melakukan manipulasi pada laporan keuangan, pelaku biasanya akan fokus pada akun yang menggunakan estimasi dan subjektifitas tertentu. Dengan merujuk penelitian Loebbecke, Eining dan Willingham (1989) penelitian ini menggunakan Receivable sebagai proksi.

SAS no.99 dan Albrecht dkk. (2008) mengindikasikan bahwa perusahaan yang memiliki aktivitas signifikan dan berlokasi di yurisdiksi berbeda memiliki peluang melakukan fraud lebih tinggi. Sehingga riset ini juga menggunakan proksi foreign operation.

Ineffective monitoring, Independent audit committee merupakan anggota komite audit yang bukan karyawan perusahaan, karyawan atau pendiri perusahaan lain yang berelasi, keluarga dari manajemen perusahaan, konsultan profesional yang digunakan perusahaan, karyawan dari supplier atau pelanggan utama perusahaan, keluarga direktur dan atau orang yang tidak memiliki transaksi signifikan dengan perusahaan (Robinson, 2002).

Organizational Structure, Skousen dkk. (2009) menyimpulkan bahwa seorang CEO dengan jabatannya mampu mendominasi pengambilan keputusan. Kemampuan mengontrol seseorang dalam pengambilan keputusan berpeluang untuk mendorong seseorang melakukan fraud.

c. Rasionalisasi, adalah elemen fraud yang paling sulit untuk diukur. Skousen dkk. (2009) menggunakan tiga proksi untuk mengukur rasionalisasi dengan pergantian auditor, laporan audit dan total akrual.

d. Capability, diukur dengan menggunakan pergantian usia CEO (Boyle, Carpenter dan Hermanson, 2012).

e. Arogansi, diukur dengan menggunakan risiko organisasi (Palmer dan Wiseman, 1999).

\section{Model Penelitian}

Untuk menjawab seluruh hipotesis yang di ajukan dalam penelitian ini, digunakan model regresi logistik sebagai berikut:

LnFraud $=\beta_{1}$ GPM $_{i t}+\beta_{2}$ SCHANGE $_{i t}+\beta_{3} A_{\text {CHANGE }}+$ $\beta_{4}$ CATA $_{i t}+\beta_{5}$ SALAR $_{i t}+\beta_{6}$ SALTA $_{i t}+\beta_{7} I N V S A L_{i t}+$ $\beta_{8} L E V_{i t}+\beta_{9}$ FINANCE $_{i t}+\beta_{11}$ OSHIP $_{i t}+\beta_{12} 5 \%$ OWN ON $_{i t}+$ $\beta_{13}$ ROA $_{i t}+\beta_{14}$ RECEIVABLE $i t+\beta_{15}$ INVENTORY $_{i t}+$ $\beta_{16}$ FOPS $_{i t}+\beta_{17}$ BDOUT $_{i t}+\beta_{18}$ AUDCOMM $_{i t}+$ $\beta_{19} A_{\text {AUDCSIZE }}+\beta_{20} I_{i N D_{i t}}+\beta_{21}$ EXPERT $_{i t}+$ $\beta_{23}$ TOTALTURN $_{i t}+\beta_{24}$ AUDCHANG $_{i t}+\beta_{25}$ AUDREPORT $_{i t}$ $+\beta_{26}$ TACC $_{i t}+\beta_{28} A G E_{i t}+\beta_{32}$ ORRISK $_{i t}+\varepsilon_{i t}$

Keterangan: 
fraud $=$ Variabel dummy, kode 1 (satu) untuk perusahaan yang melakukan kecurangan laporan keuangan, kode 0 (nol) untuk perusahaan yang tidak melakukan kecurangan laporan keuangan.

$G P M_{i t} \quad=$ Gross Profit Margin

$\operatorname{SCHANGE}_{i t} \quad=$ pertumbuhan penjualan

ACHANGE $E_{i t} \quad=$ perubahan asset selama dua tahun CATA $_{i t} \quad=$ ratio cash flow terhadap pertum-

buhan pendapatan

$S A L A R_{i t}=$ ratio penjualan terhadap piutang usaha

$S A L T A_{i t}=$ ratio penjualan terhadap total asset

$I N V S A L_{i t} \quad=$ ratio persediaan terhadap total penjualan

$L E V_{i t}$

FINANCE $E_{i t} \quad=$ permintaan perusahaan terhadap pendanaan dari pihak eksternal

${ }_{O S H I P_{i t}}=$ persentase kepemilikan saham oleh manajer

$5 \% O W N_{i t} \quad=$ persentase kepemilakan $5 \%$ saham

oleh manajer

$R O A_{i t} \quad=$ return on asset

RECEIVABLE $E_{i t} \quad$ = rasio perubahan piutang usaha terhadap penjualan

INVENTORY $Y_{i t}=$ rasio perubahan persediaan terhadap penjualan

FOPS $\quad=$ persentase penjualan diluar negeri

$B D O U T_{i t} \quad=$ persentase anggota dewan komisaris yang bukan berasal dari internal perusahaan.

AUDCOMM it $_{\text {a }} \quad$ variabel dummy, kode 1 (satu) jika perusahaan menggunakan jasa audit internal dan kode 0 (nol) jika perusahaan tidak menggunakan jasa audit internal.

$\operatorname{AUDCSIZE}_{\text {it }} \quad=$ jumlah anggota dewan komisaris yang termasuk dalam komite audit.

$I N D_{i t} \quad=$ persentase anggota komite audit yang independen dengan perusahaan.

$\operatorname{EXPERT}_{i t} \quad=$ variabel dummy, kode 1 (satu) jika komite audit tidak terdapat setidaknya satu direktur yang bekerja (pernah bekerja) di Kantor Akuntan Publik, Bank atau perusahaan Anjak Piutang, CFO, atau pernah berada di posisi senior manajer (CEO, Direkrut Utama, COO, dll) dan kode 0 (nol) jika sebaliknya.

TOTALTURN $_{\text {it }} \quad=$ jumlah anggota direksi yang keluar dari perusahaan selama dua tahun.

AUDCHANG it $_{\text {in }} \quad$ variabel dummy, kode 1 (satu) jika perusahaan melakukan pergantian auditor dan kode 0 (nol) jika sebaliknya.

AUDREPORT $_{i t} \quad=$ variabel dummy, kode 1 (satu) jika perusahaan mendapat unqualified opinion (wajar tanpa pengecualian) dalam opini audit dan kode 0 (nol) jika perusahaan mendapat unqualified opinion with additional language (wajar dengan pengecualian).

TACC $_{i t} \quad=$ total akrual dibagi total asset.

AGE = jumlah usia CEO,

ORRISK = standard deviation of return on assets

\section{HASIL DAN PEMBAHASAN}

\section{Statistik Deskriptif}

Data yang digunakan dalam penelitian ini terdiri dari 218 perusahaan dengan 3 tahun pengamatan (2013-2015), sehingga diperoleh total observasi sebanyak 654 .

Proksi GPM, SCHANGE, ACHANGE, CATA, SALAR, SALTA dan INVSAL merupakan proksi variabel Financial Stability. Berdasarkan tabel 2 tersebut dapat diketahui bahwa secara umum perusahaan sampel merupakan perusahaan yang berada pada kondisi finansial yang stabil. Proksi LEV dan FINANCE mengukur External Pressure. Berdasarkan Tabel 2 tersebut dapat diartikan bahwa tingkat tekanan eksternal yang dialami perusahaan sampel adalah tergolong tinggi.

\section{Tabel 2. Statistik Deskriptif}

\begin{tabular}{|l|l|l|l|l|l|l|l|l|l|}
\hline & GPM & $\begin{array}{l}\text { SCHA } \\
\text { NGE }\end{array}$ & $\begin{array}{l}\text { ACHA } \\
\text { NGE }\end{array}$ & $\begin{array}{l}\text { CA } \\
\text { TA }\end{array}$ & SALAR & SALTA & $\begin{array}{l}\text { INV } \\
\text { SAL }\end{array}$ & LEV & $\begin{array}{l}\text { FI- } \\
\text { NANC } \\
\text { E }\end{array}$ \\
\hline Mean & 0.18 & -0.11 & 0.09 & -0.02 & 17.29 & 0.87 & 0.17 & 0.55 & 0.47 \\
\hline $\begin{array}{l}\text { Medi- } \\
\text { an }\end{array}$ & 0.24 & 0.01 & 0.09 & -0.01 & 6.18 & 0.68 & 0.13 & 0.49 & 0.25 \\
\hline Max & 1.00 & 1.12 & 0.94 & 0.99 & 616.67 & 9.45 & 3.13 & 5.13 & 43.47 \\
\hline Min & -50.32 & -23.20 & -6.48 & -0.91 & 0.07 & 0.01 & 0.00 & 0.01 & -22.12 \\
\hline $\begin{array}{l}\text { Std. } \\
\text { Dev. }\end{array}$ & 2.09 & 1.18 & 0.31 & 0.12 & 48.14 & 0.84 & 0.20 & 0.47 & 2.26 \\
\hline $\begin{array}{l}\text { Skew- } \\
\text { ness }\end{array}$ & -22.12 & -13.96 & -14.40 & -0.28 & 6.94 & 2.98 & 6.37 & 5.63 & 9.19 \\
\hline $\begin{array}{l}\text { Kurto- } \\
\text { sis }\end{array}$ & 528.03 & 246.97 & 305.41 & $\begin{array}{l}18.3 \\
6\end{array}$ & 62.12 & 22.29 & $\begin{array}{l}81.9 \\
8\end{array}$ & $\begin{array}{l}46.1 \\
7\end{array}$ & 229.22 \\
\hline
\end{tabular}

OSHIP dan OWN mengukur tingkat Personal Financial Need perusahaan. Data statistic pada Tabel 3 menunjukkan bahwa secara umum tingkat kebutuhan finansial individual pada perusahaan tergolong tinggi. Data ROA menunjukkan bahwa perusahaan memiliki Financial Target yang relative tinggi. Nature of Industry perusaan ditunjukkan oleh rasio RECEIVABLE, INVENTORY dan FOPS. Berdasarkan data ketiga proksi tersebut dapat diketahui bahwa risiko karakteristik industri pada perusahaan sampel tergolong tinggi. Ineffective Monitoring diukur melalui BDOUT, AUDSIZE. EXPERT dan IND, data statistic menunjukkan bahwa unit yang bertugas dalam melaksanakan fungsi pengawasan secara umum telah bekerja dengan efektif.

\section{Tabel 3 Statistik Deskriptif (lanjutan)}

\begin{tabular}{|c|c|c|c|c|c|c|c|c|}
\hline & $\begin{array}{c}\text { OSH } \\
\text { IP }\end{array}$ & $\begin{array}{c}\text { OW } \\
\mathrm{N}\end{array}$ & $\begin{array}{c}\text { RO } \\
\mathrm{A}\end{array}$ & $\begin{array}{c}\text { RECEIV- } \\
\text { ABLE }\end{array}$ & $\begin{array}{c}\text { INVEN- } \\
\text { TORY }\end{array}$ & $\begin{array}{c}\text { FO } \\
\text { PS }\end{array}$ & $\begin{array}{c}\text { BDO } \\
\text { UT }\end{array}$ & $\begin{array}{c}\text { AU } \\
\text { DCS } \\
\text { IZE }\end{array}$ \\
\hline Mean & 0.84 & 0.51 & $\begin{array}{c}0.0 \\
5\end{array}$ & 0.01 & 0.08 & 0.08 & 0.33 & 1.12 \\
\hline $\begin{array}{c}\text { Medi- } \\
\text { an }\end{array}$ & 0.00 & 0.00 & $\begin{array}{c}0.0 \\
4\end{array}$ & 0.00 & 0.00 & 0.00 & 0.25 & 1.00 \\
\hline Max & 73.93 & $\begin{array}{c}73.9 \\
3\end{array}$ & $\begin{array}{c}0.9 \\
8\end{array}$ & 10.25 & 39.49 & 1.00 & 16.67 & 4.00 \\
\hline Min & 0.00 & 0.00 & - & -22.18 & -18.90 & 0.00 & 0.00 & 0.00 \\
\hline $\begin{array}{c}\text { Std. } \\
\text { Dev. }\end{array}$ & 6.08 & 5.51 & $\begin{array}{c}0.1 \\
3\end{array}$ & 1.11 & 2.06 & 0.21 & 1.12 & 0.37 \\
\hline $\begin{array}{c}\text { Skew- } \\
\text { ness }\end{array}$ & 9.66 & $\begin{array}{c}12.0 \\
0\end{array}$ & $\begin{array}{c}2.3 \\
8\end{array}$ & -10.05 & 10.14 & 2.97 & 14.43 & 3.43 \\
\hline $\begin{array}{c}\text { Kurto- } \\
\text { sis }\end{array}$ & 105.9 & $\begin{array}{c}152 . \\
4\end{array}$ & $\begin{array}{c}47 . \\
30\end{array}$ & 265.78 & 231.44 & $\begin{array}{c}11.1 \\
3\end{array}$ & 210.9 & 8 \\
\hline
\end{tabular}

Organizational structure diukur melalui TOTALTURN, dimana data statistic menunjukkan bahwa struktur organisasi perusahaan sampel tergolong kompleks dan tidak stabil. Aspek Rationalization diukur melalui TACC, AUDCHANGE dan AUDREPORT. Proksi AUDREPORT menunjukkan bahwa sebahagian besar perusahaan sampel memperoleh opini Unqualified, dengan kata lain memiliki laporan keuangan yang sudah sesuai dengan standar pelaporan. Dari sisi AUDCHANGE terlihat bah- 
wa mayoritas perusahaan sampel tidak melakukan pergantian auditor, yang artinya perusahaan sampel menganggap tindak kecurangan secara rasional tidak dapat diterima. Aspek Capability diukur melalui AGE, yang menunjukkan bahwa usia rata-rata CEO tergolong senior. Dengan kata lain perusahaan sampel memiliki CEO dengan tingkat capability yang tinggi. Aspek Arrogance pada riset ini diukur melalui ORRISK, dimana berdasarkan data statistic terlihat bahwa tingkat risiko perusahaan sampel relatif tinggi. Sehingga dapat disimpulkan bahwa tingkat arogansi direksi perusahaan sampel juga tergolong tinggi.

\section{Tabel 4. Statistik Deskriptif (lanjutan)}

\begin{tabular}{|c|c|c|c|c|c|}
\hline & IND & TOTALTURN & TACC & AGE & ORRISK \\
\hline Mean & 0.94 & 2.01 & -0.03 & 53.02 & 0.05 \\
\hline Median & 0.67 & 1.00 & -0.03 & 53.00 & 0.04 \\
\hline Max & 66.67 & 12.00 & 2.23 & 86.00 & 0.98 \\
\hline Min & 0.00 & 0.00 & -3.32 & 27.00 & -1.57 \\
\hline Std. Dev. & 4.48 & 2.10 & 0.26 & 8.00 & 0.13 \\
\hline Skewness & 14.60 & 1.44 & -4.05 & 0.01 & -2.36 \\
\hline Kurtosis & 214.42 & 5.29 & 70.58 & 3.44 & 46.61 \\
\hline
\end{tabular}

Tabel 5 menunjukkan bahwa persentase perusahaan yang berpeluang besar melakukan fraud adalah 38\%, artinya sebahagian besar perusahaan sampel tergolong pada perusahaan dengan peluang melakukan tindak kecurangan pelaporan keuangan yang kecil. Variabel EXPERT menunjukkan anggota komite audit yang memiliki keahlian dibidang akuntansi atau keuangan mencapai $61 \%$, dengan kata lain sebagian besar anggota komite audit adalah mereka yang memiliki keahlian dalam mendeteksi tindak fraud.

\section{Tabel 5 Statistik Deskriptif (lanjutan)}

\begin{tabular}{|c|c|c|c|c|c|c|c|c|}
\hline & $\begin{array}{c}\text { FRA } \\
\text { UD }\end{array}$ & $\%$ & $\begin{array}{c}\text { EX- } \\
\text { PER } \\
\text { T }\end{array}$ & $\%$ & $\begin{array}{c}\text { AUDC } \\
\text { HANG } \\
\text { E }\end{array}$ & $\%$ & $\begin{array}{c}\text { AU } \\
\text { DRE } \\
\text { POR } \\
\text { T }\end{array}$ & $\%$ \\
\hline $\begin{array}{c}\text { PERSEN- } \\
\text { TASE } \\
\text { SKOR 1 }\end{array}$ & 244 & 0.38 & 394 & 0.61 & 138 & 0.21 & 431 & 0.66 \\
\hline $\begin{array}{c}\text { PERSEN- } \\
\text { TASE } \\
\text { SKOR 0 }\end{array}$ & 406 & 0.62 & 256 & 0.39 & 512 & 0.79 & 219 & 0.34 \\
\hline TOTAL & 650 & & 650 & & 650 & & 650 & \\
\hline
\end{tabular}

Hasil Pengujian Hipotesis

Penelitian ini menggunakan regresi logistik. Data pada penelitian ini diolah dengan bantuan software EVIEWS.9. hasil pengujian disajikan pada Tabel 6. Tabel 6 menunjukkan bahwa model fit (Prob LR Statistik: 0.000, $<5 \%$ ). Model penelitian ini mampu menjelaskan besar kecilnya peluang terjadi fraud sebesar $25.67 \%$. sisanya dijelaskan oleh variabel lain yang belum diujikan dalam penelitian ini. Hasil pengujian juga menunjukkan bahwa hanya variabel CATA, SALAR dan TACC yang mempengaruhi peluang terjadinya fraud. CATA dan SALAR adalah proksi Financial Stability yang merupakan bagian dari Pressure pada Fraud Pentagon Theory. Sedangkan TACC adalah proksi dari Rationalization. Setiap peningkatan rasio CATA sebesar 1 satuan, maka akan meningkatkan peluang fraud sebesar 390.608. Pada SALAR, setiap perubahan aser sebesar 1 rupiah akan memperbesar peluang terjadinya fraud sebesar 10.75647. Sedangkan pada TACC, setiap peningkatan rasio total akrual sebesar 1 satuan, akan memperbesar peluang perusahaan melakukan tindakan fraudsebesar 4.91. Dengan demikian dapat disimpulkan bahwa hanya aspek Financial Stability dan Rasionalitas yang mempengaruhi tindakan fraud yang dilakukan oleh sebahagian besar perusahaan di Indonesia.

Tabel 6. Hasil Pengujian Hipotesis

\begin{tabular}{|c|c|c|c|c|c|}
\hline Variable & Coefficient & Std. Error & z-Statistic & Odd Ratio & Prob. \\
\hline $\mathrm{C}$ & -1.131773 & 1.948034 & -0.580982 & & 0.5613 \\
\hline GPM & -0.0454 & 0.138471 & -0.327864 & & 0.743 \\
\hline SCHANGE & 0.024378 & 0.124807 & 0.195323 & & 0.8451 \\
\hline ACHANGE & 2.374007 & 0.470442 & 5.046331 & 10.75647 & $0.0000^{\star \star * *}$ \\
\hline CATA & 12.86733 & 1.574223 & 8.173763 & 390608.3 & $0.0000^{\star \star *}$ \\
\hline SALAR & -0.002294 & 0.002431 & -0.943844 & & 0.3452 \\
\hline SALTA & -0.239779 & 0.14987 & -1.599909 & & 0.1096 \\
\hline INVSAL & 0.14568 & 0.608193 & 0.23953 & & 0.8107 \\
\hline LEV & 0.197439 & 0.275397 & 0.716925 & & 0.4734 \\
\hline FINANCE & -0.027148 & 0.083281 & -0.325986 & & 0.7444 \\
\hline OSHIP & -0.024715 & 0.046772 & -0.528419 & & 0.5972 \\
\hline OWN & 0.02215 & 0.052116 & 0.425017 & & 0.6708 \\
\hline RECEIVABLE & -0.011225 & 0.085113 & -0.131887 & & 0.8951 \\
\hline INVENTORY & -0.033903 & 0.062258 & -0.544559 & & 0.5861 \\
\hline FOPS & 0.153962 & 0.475709 & 0.323648 & & 0.7462 \\
\hline BDOUT & -1.41012 & 0.961657 & -1.466343 & & 0.1426 \\
\hline AUDCSIZE & 0.190213 & 0.611995 & 0.310808 & & 0.7559 \\
\hline IND & 2.275946 & 1.928409 & 1.18022 & & 0.2379 \\
\hline EXPERT & 0.072707 & 0.202809 & 0.358502 & & 0.72 \\
\hline TOTALTURN & -0.051261 & 0.049525 & -1.035057 & & 0.3006 \\
\hline AUDCHANGE & -0.011782 & 0.254322 & -0.046327 & & 0.963 \\
\hline AUDREPORT & 0.046736 & 0.223635 & 0.208985 & & 0.8345 \\
\hline TACC & 1.590376 & 0.662174 & 2.401749 & 4.91053 & $0.0163^{* \star}$ \\
\hline AGE & -0.014597 & 0.011725 & -1.244978 & & 0.2131 \\
\hline ORRISK & -8.778252 & 13.97681 & -0.628058 & & 0.53 \\
\hline ROA & 10.12337 & 14.05861 & 0.720084 & & 0.4715 \\
\hline \multicolumn{2}{|c|}{ McFadden R-squared } & \multicolumn{4}{|r|}{0.256708} \\
\hline LR statistic & & & & & 220.843 \\
\hline
\end{tabular}




\begin{tabular}{|l|c|}
\hline & \\
Prob (LR statistic) & 0.00 \\
\hline
\end{tabular}

\section{SIMPULAN}

Penelitian ini bertujuan untuk menguji apakah berbagai prediktor fraud pentagon theory yakni aspek fraud pentagon theory yakni: Pressure, Opportunity, Rationalization, Capability dan Arrogance mampu menjelaskan financial statement fraud di Indonesia. Dan menguji alternatif proksi Capability dan Arrogance. Hasil pengujian menunjukkan bahwa: hanya dua proksi elemen Pressure dan satu proksi Rationalization yang dapat menjelaskan peluang terjadinya kecurangan pada laporan keuangan. Proksi Capability dan Arrogance yang diusulkan pada riset ini, tidak terbukti dapat menjelaskan peluang kejadian fraud pada laporan keuangan.

Penelitian ini memiliki sejumlah keterbatasan; menggunakan besaran kepemilikan manajerial diatas $5 \%$, jumlah kepemilihan saham oleh manajemen, penjualan ke luar negeri sebagai proksi akan menyebakan sebahagian besar data menjadi kecil (mendekati nol), hal ini tentu menyebabkan kemampuan data dalam menjelaskan variabel dependen menjadi kecil sehingga dalam penelitian ini menjadi tidak signifikan. Penelitian selanjutkan disarankan menggunakan proksi lain seperti agenda rapat dan jumlah temuan komite audit yang terkait fraud, remunerasi direksi, dan melakukan pengujian sesuai dengan cluster industri. Penggunakan proksi yang menggunakan persediaan, akan menyebabkan banyak perusahaan terutama sektor jasa menjadi tidak bisa disertakan sebagai sampel. Sehingga penelitian berikutnya disarankan menggunakan proksi financial stability lainnya.

Proksi fraud diamond (capability) yaitu usia ceo dan fraud pentagon (arrogance) yaitu risiko organisasi yang digunakan dalam penelitian ini tidak dapat menjelaskan peluang terjadinya fraud. Penelitian selanjutnya disarankan menggunakan jumlah jabatan yang dipegang oleh seorang ceo dalam waktu yang sama atau menggunakan banyaknya variasi jenis industri yang pernah dipimpin oleh ceo sebagai proksi dari capability. Untuk arogansi, penelitian selanjutnya dapat menggunakan proksi risiko manajerial atau proksi risiko perusahaan yang lainnya.

\section{REFERENCES}

Abdullahi, R. dan Mansor, N., (2015), Fraud Triangle Theory and Fraud Diamond Theory. Understanding the Convergent and Divergent for Future Research, International Journal of Academic Research in Accounting, Finance and Management Sciences, Vol 5 No 4 October 2015, page 38-45

Association of Certified Fraud Examiners. 2014. Report to the nation on occupational fraud and abuse (2014 global fraud study). Retrieved from http://www.acfe.com/rttn/rttn-2014.pdf.

Association of Certified Fraud Examiners, (2016), Report to the nation on occupational fraud and abuse
(2016 global fraud study), Retrieved from http://www.acfe.com rttn/rttn-2016.pdf.

Albrecht, W. S., Albrecht, C. dan Albrecht, C. C., (2008), Current Trends in Fraud and its Detection: A Global Perspective, Information Security Journal Vol 17, Retrieved from www.ebscohost.com on 11th June, 2014.

Annisya, M., Lindrianasari dan Asmaranti, Y., (2016), Pendeteksian Kecurang Laporan Keuangan Menggunakan Fraud Diamond. Jurnal Bisnis dan Ekonomi (JBE), Vol 23 No 1, Maret 2016, page $72-89$

Ardiyani, S. dan Utaminingsih, N. S., (2015), Analisis Determinan Financial Statement Melalui Pendekatan Fraud Triangle, Accounting Analysis Journal, Vol 4 No 1.

Beasley, M., Carcello, J., Hermanson, D. dan Lapides, P. D., (2000), Fraudulent financial reporting: Consideration of industry traits and corporate governance mechanisms. Accounting Horizons, Vol 14 No 4, page 441-454.

Beneish, M., (1997), Detecting GAAP violation: Implications for assessing earnings management among firms with extreme financial performance. Journal of Accounting and Public Policy, Vol 16 No 3, page 271-309.

Beneish, M., (2012), Fraud Detection and Expected Return, http://papers.ssrn.com/ abstract_id=1998387

Boyle, D. M., Carpenter, B. W., dan Hermanson, D., (2012), CEOs, CFOs and Accounting Fraud. CPA Journal, Vol 82 No 1, page 62-65.

Cressey, D., (1953), Other People's Money; a Study in the Social Psychology of Embezzlement, Glencoe, IL, Free Press.

Dechow, P. M., Ge, W. dan Schrand, C., (2009), Understanding earnings quality. Working paper, University of California, Berkeley, University of Washington, and University of Pennsylvania.

Horwarth, C., (2012), The Mind Behind The fraud sters Crime: Key Behavioral and Environmental Element.

Jeppesen, K. K. dan Leder, C., (2016), Auditors' experience with corporate psychopaths. Journal of Financial Crime, Vol 23 No 4, page 870-881 Permanent link to this document: http://dx.doi.org/10.1108/JFC-05-2015-0026

Kaminski, K. A. dan Guan, T. S. W. L., (2004), Can financial ratios detect fraud ulent financial reporting?, Managerial Auditing Journal, Vol 19 No 1, page $15-28$.

Khanin, D. R. V. dan Mahto., (2012), Regulatory risk, borderline legality, fraud and financial restatement. International Journal of Accounting $\mathcal{E}$ Information Management, Vol 20 No 4, page 37 94

http://dx.doi.org/10.1108/18347641211272713

Kurniawati, (2012), Analisis Faktor-Faktor Yang Mempengaruhi Financial Statement Fraud Dalam Perspektif Fraud Triangle. Skripsi. Univer- 
sitas Diponegoro: Semarang.

Loebbecke, Eining, J. M., dan Willingham, J., (1989), Auditors' experience with material irregularities: Frequency, nature, and detestability. Auditing: A Journal of Practice \& Theory Vol 9 Fall, page 128.

Manurung, D. T. H. dan Hardika, A. L., (2015), Analysis of Factors That Influence Financial Statement Fraud in The Perspective Fraud Diamond: Empirical Study on Banking Companies Listed on The Indonesia Stock Exchange Year 2012 To 2014. Proceedings of the International Conference on Accounting Studies (ICAS).

Marianan, M. dan Hakim, L., (2016), Pendeteksian Pemanipulasian Laba: Pengujian Teori Fraud Triangle dan Dampak Pengadopsian International Financial Reporting Standard (IFRS), Simposium Nasional Akuntansi XIX, Lampung.

Molida, R., (2011), Analisis Financial Stability, Personal Financial Need dan Ineffective Monitoring pada Financial Statement Fraud dalam Perspektif Fraud Triangle, Skripsi, Universitas Diponegoro: Semarang.

Norbarani, (2012), Pendeteksian Kecurangan Laporan Keuangan Dengan Analisis Fraud Triangle Yang Diadopsi Dalam SAS No.99, Skripsi, Universitas Diponegoro: Semarang.

Palmer, T.B. dan Wiseman, R.M., (1999), Decoupling risk taking from income stream uncertainty: a holistic model of risk, Strategic Management Journal, Vol 20, page 1037-62.

Repousis, S., (2016), Using Beneish Model to Detect Corporate Financial Statement fraud In Greece, Journal of Financial Crime, Vol 23 No 4, page $1063-1073$.

Robinson, D., (2002), Audit Committee Composition and Financial Reporting Problems. Stillwater, Oklahoma: Oklahoma State University.

SAS No.99, (2002), Consideration of Fraud in a Financial Statement Audit, AICPA. New York

Sihombing K. S., (2014), Analisis Fraud Diamond dalam Mendeteksi Financial Statement fraud: Studi Empiris Pada Perusahaan Manufaktur yang Terdaftar di Bursa Efek Indonesia (BEI). Journal of Accounting Fakultas Ekonomika dan Bisnis Universitas Diponegoro.

Skousen, C. J., Smith, K. R. dan Wright, C. J., (2009), Detecting and Predicting Financial Statement fraud: The Effectiveness of The Fraud Traingle $\begin{array}{lll}\text { and SAS No. } & \end{array}$ http://ssrn.com/abstract=1295494.

Tarjo dan Herawati, N., (2015) Application of Beneish M-Score Models and Data Mining to Detect Financial fraud. Procedia - Social and Behavioral Sciences, Vol 211 page $924-930$.

Tessa G. C., dan Harto, P., (2016), Fraudulent Financial Reporting: Pengujian Teori Fraud Pentagon Pada Sektor Keuangan Dan Perbankan Di Indonesia, Simposium Nasional Akuntansi XIX, Lampung.
Wolfe, D., dan Hermanson, D. R. (2004), The Fraud Diamond: Considering four elements of fraud, The CPA Journal, Vol 74 No 12, page 38-42.

Yesiariani, M. dan Rahayu, I., (2016). Analisis Fraud Diamond dalam Mendeteksi Financial Statement fraud (Studi Empiris pada Perusahaan LQ-45 yang Terdaftar di Bursa Efek Indonesia Tahun 2010 - 2014). Simposium Nasional Akuntansi XIX, Lampung.

\section{LAMPIRAN}

\begin{tabular}{|c|c|c|}
\hline Variabel & $\begin{array}{c}\text { Definisi } \\
\text { Operasional } \\
\end{array}$ & Pengukuran \\
\hline \multicolumn{3}{|r|}{ Independen } \\
\hline $\begin{array}{l}\text { Financial } \\
\text { Stability }\end{array}$ & $\begin{array}{l}\text { Suatu kondisi } \\
\text { dimana } \\
\text { mekanisme } \\
\text { ekonomi } \\
\text { dalam peneta- } \\
\text { pan harga, } \\
\text { alokasi dana } \\
\text { dan pengel- } \\
\text { olaan risiko } \\
\text { berfungsi baik } \\
\text { secara men- } \\
\text { dan per- } \\
\text { dukung tumbuhan } \\
\text { ekonomi. }\end{array}$ & 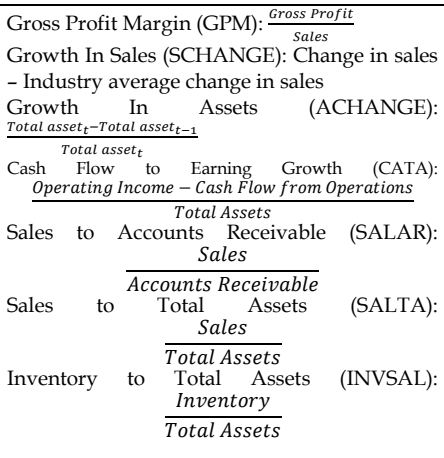 \\
\hline $\begin{array}{l}\text { Exte } \\
\text { rnal } \\
\text { press } \\
\text { ure }\end{array}$ & $\begin{array}{l}\text { Tekanan yang } \\
\text { berlebihan } \\
\text { bagi mana- } \\
\text { jemen untuk } \\
\text { memenuhi } \\
\text { persyaratan } \\
\text { atau harapan } \\
\text { dari pihak } \\
\text { ketiga. }\end{array}$ & 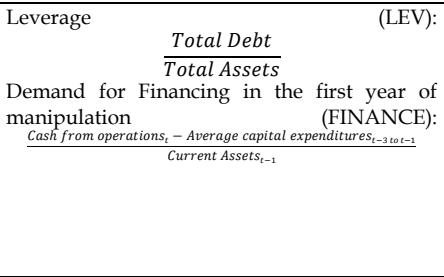 \\
\hline $\begin{array}{l}\text { Persona } \\
l \\
\text { financia } \\
\text { l need }\end{array}$ & $\begin{array}{l}\text { Keadaan } \\
\text { dimana keu- } \\
\text { angan perus- } \\
\text { ahaan turut } \\
\text { dipengaruhi } \\
\text { oleh kondisi } \\
\text { keuangan para } \\
\text { eksekutif } \\
\text { perusahaan }\end{array}$ & $\begin{array}{l}\text { Cumulative Percentage of Ownership in the } \\
\text { firm held by insider (OSHIP): } \\
\text { Shares owned by management } \\
\text { Common Shares Outstanding } \\
\text { Cumulative Percentage of Ownership in the } \\
\text { firm held by management who hold } 5 \% \text { of } \\
\text { outstanding shares or more ( } 5 \% \text { OWN): } \\
\text { Number of management whon hold } 5 \% \text { of the eutstanding shares or more } \\
\text { Conmon shares outstanding }\end{array}$ \\
\hline $\begin{array}{l}\text { Financi } \\
\text { al } \\
\text { Target }\end{array}$ & $\begin{array}{l}\text { Tekanan } \\
\text { berlebihan } \\
\text { pada mana- } \\
\text { jemen untuk } \\
\text { mencapai } \\
\text { target keu- } \\
\text { angan yang } \\
\text { dipatok oleh } \\
\text { direksi atau } \\
\text { manajemen. }\end{array}$ & $R O A=\frac{\text { Earning After } \text { Tax }_{t-1}}{\text { Total Assets } s_{t-1}}$ \\
\hline $\begin{array}{l}\text { Nature } \\
\text { of } \\
\text { industr } \\
y \\
1 .\end{array}$ & $\begin{array}{l}\text { Berkaitan } \\
\text { dengan mun- } \\
\text { culnya risiko } \\
\text { bagi perus- } \\
\text { ahaan yang } \\
\text { berkecimpung } \\
\text { dalam industri } \\
\text { yang melibat- } \\
\text { kan estimasi }\end{array}$ & 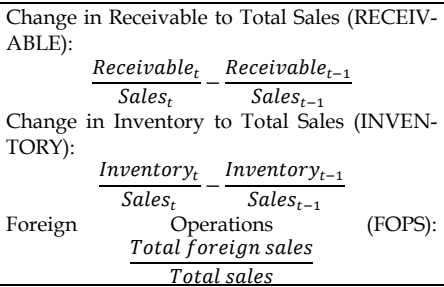 \\
\hline
\end{tabular}




\begin{tabular}{|c|c|c|}
\hline & $\begin{array}{l}\text { dan pertim- } \\
\text { bangan yang } \\
\text { signifikan jauh } \\
\text { lebih besar. }\end{array}$ & \\
\hline $\begin{array}{l}\text { Ineffecti } \\
\text { ve } \\
\text { monitor } \\
\text { ing } \\
1 .\end{array}$ & $\begin{array}{l}\text { keadaan di- } \\
\text { mana perus- } \\
\text { ahaan tidak } \\
\text { memiliki unit } \\
\text { pengawasan } \\
\text { yang efektif } \\
\text { dalam meman- } \\
\text { tau kinerja } \\
\text { perusahaan. }\end{array}$ & $\begin{array}{l}\text { Board Composition (BDOUT): Percentage of } \\
\text { board members who are outside members } \\
\text { Audit Committees (AUDCSIZE): The number } \\
\text { of board members who are on the audit } \\
\text { committee } \\
\text { Independent audit in Audit Committee (IND): } \\
\text { Percentage of audit committee members who } \\
\text { are independent of the company. } \\
\text { Director in Audit Committee who has Expert } \\
\text { (EXPERT).: Indicator variable with the value } \\
\text { of } 1 \text { if the audit committee does not include at } \\
\text { least one director who is (or has been) a CPA, } \\
\text { investment banker or venture capitalist, } \\
\text { served as CFO or controller, or has held a } \\
\text { senior management position (CEO, President, } \\
\text { COO, VP, etc.) with financial responsibilities. }\end{array}$ \\
\hline $\begin{array}{l}\text { Organiz } \\
\text { ational } \\
\text { structur } \\
e\end{array}$ & $\begin{array}{l}\text { Struktur or- } \\
\text { ganisasi yang } \\
\text { kompleks dan } \\
\text { tidak stabil. }\end{array}$ & $\begin{array}{l}\text { CEO Power (TOTALTURN): Number of } \\
\text { executives that left the firm in the two years } \\
\text { prior to fraud. }\end{array}$ \\
\hline $\begin{array}{l}\text { Auditor } \\
\text { Change } \\
2 .\end{array}$ & \begin{tabular}{lr}
\multicolumn{2}{l}{ Pergantian } \\
auditor dalam \\
pemberian jasa \\
yang dil- \\
akukan oleh \\
suatu KAP \\
terhadap suatu \\
entitas atau \\
perusahaan
\end{tabular} & $\begin{array}{l}1 \text { jika terjadi pergantian auditor dan } 0 \text { jika } \\
\text { tidak }\end{array}$ \\
\hline $\begin{array}{l}\text { Audit } \\
\text { Report }\end{array}$ & $\begin{array}{l}\text { Laporan yang } \\
\text { menyatakan } \\
\text { bahwa dil- } \\
\text { pemeriksaan } \\
\text { telah sesuai } \\
\text { akukan san } \\
\text { dengan norma } \\
\text { pemeriksaan } \\
\text { akuntan, } \\
\text { disertai } \\
\text { dengan pen- } \\
\text { dapat (opini) } \\
\text { mengenai } \\
\text { kewajaran } \\
\text { laporan keu- } \\
\text { angan perus- } \\
\text { ahaan yang } \\
\text { diperiksa. }\end{array}$ & $\begin{array}{l}\text { AUDREPORT } \\
=\text { dummy variable for an audit where } 1 \text { (one) } \\
=\text { unqualified opinion and } 0 \text { (zero) } \\
=\text { unqualified opinion with additional languag }\end{array}$ \\
\hline $\begin{array}{l}\text { Total } \\
\text { Accrual }\end{array}$ & $\begin{array}{l}\text { Total transaksi } \\
\text { pengakuan } \\
\text { pendapatan } \\
\text { atau beban, } \\
\text { sebelum uang } \\
\text { diterima atau } \\
\text { dibayarkan. }\end{array}$ & $T$ Acc $=\frac{\text { total accruals }}{\text { total assets }}$ \\
\hline $\begin{array}{l}\text { Capabi } \\
\text { lity }\end{array}$ & & Age $=$ jumlah usia CEO \\
\hline $\begin{array}{l}\text { Arogan } \\
\text { si }\end{array}$ & $\begin{array}{lr}\text { income stream } \\
\text { uncertainty } \\
\text { dan pilihan } \\
\text { proaktif mana- } \\
\text { jemen atas } \\
\text { alokasi sum- } \\
\begin{array}{l}\text { berdaya pe- } \\
\text { rusahaan. }\end{array}\end{array}$ & $\begin{array}{l}\text { ORRISK = standard deviation of return on } \\
\text { assets }\end{array}$ \\
\hline \multicolumn{3}{|l|}{ Dependen } \\
\hline $\begin{array}{l}\text { Financi } \\
\text { al } \\
\text { Stateme } \\
\text { nt fraud }\end{array}$ & \begin{tabular}{l}
\multicolumn{2}{l}{ Penyajian } \\
kondisi keu- \\
angan suatu \\
perusahaan \\
yang disengaja \\
salah yang \\
dapat tercapai \\
melalui salah
\end{tabular} & Beneish M-Score \\
\hline
\end{tabular}

\begin{tabular}{|l|l|l|}
\hline saji yaitu & \\
penghilangan \\
sejumlah nilai \\
di laporan \\
keuangan yang \\
bertujuan \\
untuk menge- \\
labui \\
pengguna \\
laporan keu- \\
angan,
\end{tabular} \mid

